\author{
Alicja Sekula \\ Politechnika Gdańska \\ e-mail: Alicja.Sekula@zie.pg.gda.pl
}

\title{
STOSOWANIE MECHANIZMU WYRÓWNANIA POZIOMEGO W WOJEWÓDZTWACH - SKUTKI DLA DOCHODÓW BUDŻETÓW
}

\author{
APPLICATION OF THE HORIZONTAL \\ FISCAL EQUALISATION MECHANISM \\ IN POLISH VOIVODESHIPS - IMPACT \\ ON THE BUDGET REVENUES
}

DOI: $10.15611 /$ pn.2018.528.17

JEL Classification: H77, H71, H23

Streszczenie: Publikacja poświęcona jest zagadnieniu mechanizmu wyrównywania poziomego na szczeblu regionalnym. Celem artykułu, oprócz przedstawienia przesłanek i zasad regulujących jego funkcjonowanie, jest ocena wpływu na sytuację dochodową budżetów województw, zwłaszcza że tylko na tym szczeblu wprowadzono od 2015 r. istotne zmiany, zarówno po stronie naliczania, jak i rozdziału środków. Na podstawie uzyskanych wyników stwierdzono, że po modyfikacji reguł jednostki beneficjenci uzyskują nawet 6 razy mniejsze wpływy z tej części subwencji ogólnej w stosunku do lat wcześniejszych. Po nowelizacji ustawy globalna kwota części regionalnej uległa redukcji o blisko 2/3, a poziom zmniejszenia wpłat w przypadku mazowieckiego (jako dominującego regionu w systemie wpłat zwanym także ,janosikowym”) w przeliczeniu na osobę sięgnął blisko 50\%. Zakres czasowy badań objął lata 2004-2017.

Słowa kluczowe: wyrównywanie poziome, część regionalna subwencji ogólnej, „janosikowe", dochody województw, wpłaty na część regionalną.

Summary: The publication is devoted to the issue of the horizontal fiscal equalisation mechanism at the regional level. The aim of the article, apart from presenting the premises and rules governing its functioning, is to assess its impact on voivodeship budgets revenue situation, especially that only on regional level significant changes both on collection and distribution funds side have been introduced since 2015. Based on the obtained results, it has been found that after modifying the rules, beneficiary units receive up to six times lower financial inflows from this part of the general subsidy in relation to previous years. After the law change, the global amount of the regional part of general subsidy was reduced by nearly $2 / 3$, and the level of reduction of payments in the case of Mazowieckie (as the dominant region in the transferring funds system) per capita reached nearly 50\%. The time range of the research covered the years 2004-2017.

Keywords: horizontal fiscal equalisation, regional part of the general subsidy, voivodships revenues, intergovernemntal transfers. 


\section{Wstęp}

Współczesne rozumienie finansów publicznych przyjmuje, że obejmują one politykę finansową, budżetową oraz społeczną. Realizacja pierwszej z nich dokonuje się w trzech obszarach: stabilizacji gospodarki, alokacji czynników produkcji i redystrybucji dochodów. Jej prowadzenie stanowi podstawę do wyróżnienia trzech funkcji państwa: stabilizacyjnej, alokacyjnej i redystrybucyjnej. Najczęściej utożsamiane są one z funkcjami finansów publicznych, choć zwraca się uwagę, że w literaturze poświęconej finansom publicznym funkcje mają specyficzny, pieniężny charakter [Owsiak 2005, s. 66-67]. Koncepcja wydzielenia trzech funkcji istnieje od ponad półwiecza praktycznie w niezmienionej postaci [Musgrave 1959; Musgrave 2008, s. 340].

Z racji problematyki podjętej w niniejszym artykule szerzej omówiona została funkcja redystrybucyjna mająca na celu korygowanie nadmiernych rozpiętości dochodów. Może odbywać się między różnymi rodzajami podmiotów, w tym między podmiotami publicznymi. Jednostki samorządowe uczestniczą $\mathrm{w}$ realizacji funkcji redystrybucyjnej finansów publicznych m.in. poprzez system subwencjonowania, aczkolwiek należy podkreślić, że mechanizm formowania dochodów budżetowych jednostek samorządu terytorialnego jest kształtowany jest zastosowanie dwóch form podziału środków publicznych: pionowej i poziomej.

Pionowy podział dochodów polega na przypisaniu ich poszczególnym szczeblom władz w strukturze terytorialnej kraju. Poziomy podział dochodów przeprowadzony jest w obrębie jednostek funkcjonujących na tym samym szczeblu terytorialnej organizacji władzy.

\section{Przesłanki stosowania oraz idea poziomego podziału dochodów}

Pionowy podział dochodów, zwany wertykalnym, w systemie dochodów samorządu terytorialnego ma kluczowe znaczenie. Dominuje nad podziałem poziomym, inaczej horyzontalnym. Choć wpływ tego ostatniego w różnych krajach jest inny, to zawsze traktowany jest jako uzupełniający.

Pierwszy powinien odbywać się zgodnie z zasadą adekwatności, czyli odpowiednio do liczby, rodzajów i kosztów wykonania zadań. Praktyka i doświadczenie Polski, jak i innych krajów pokazują, że nie jest możliwa taka jego konstrukcja, by zasada adekwatności została zrealizowana w odniesieniu do wszystkich jednostek danego szczebla samorządowego. Dlatego powszechnie stosuje się system subwencjonowania, którego zadaniem jest uzupełnianie dochodów własnych. Przy jego konstrukcji jedną z podstawowych decyzji jest wybór formy tego systemu. Najogólniej wyróżnia się dwa rodzaje systemów wyrównania:

a) pionowy, w którym uzupełnianie dochodów odbywa się za pomocą środków publicznych pochodzących z budżetu państwa, 
b) poziomy, w którym uzupełnianie dochodów odbywa się za pomocą środków publicznych pochodzących z innych jednostek samorządu terytorialnego tego samego szczebla, przy czym przepływ środków odbywa się od jednostek o dochodach wyższych do jednostek o dochodach niższych.

System uzupełniania oznaczony symbolem b) nie istnieje samodzielnie, choć w różnych państwach może mieć różne znaczenie i wpływ na ostateczną wielkość samorządowych budżetów. W praktyce spotyka się dwa przypadki: gdy w państwie stosowana jest wyłącznie redystrybucja pionowa (a) lub redystrybucja pionowa oraz uzupełniająca ją redystrybucja pozioma (a i b). Dominujące znaczenie tej pierwszej wynika z konieczności zapewnienia założonego standardu życia i świadczenia usług publicznych na co najmniej minimalnie określonym poziomie w skali kraju niezależnie od miejsca zamieszkania. Dlatego niwelowanie dysproporcji w terytorialnym rozkładzie dochodów własnych odbywa się głównie z budżetu państwa. Ta forma redystrybucji wiąże się jednak ze wzmocnieniem kompetencji organów centralnych, a także z uzależnieniem sytuacji finansowej jednostek terytorialnych na poszczególnych szczeblach od sytuacji budżetu państwa [Patrzałek 2010, s. 200]. Wśród europejskich krajów z wysokim stopniem wyrównania pierwszy system (pionowy) spotykany jest w Wielkiej Brytanii, a drugi (pionowy i poziomy) ma dominujące znaczenie w Szwecji [Swianiewicz 2003, s. 107].

Przesłanek pojawienia się redystrybucji poziomej w finansach samorządowych dostarczyła sytuacja w powojennej Europie. Na skutek intensywnego wzrostu wydatków publicznych europejskie budżety państwowe zaczęły być trwale deficytowe [Sochacka-Krysiak 2009, s. 195]. Wprowadzenie do systemu prawnego i finansowego redystrybucji poziomej pozwoliło zmniejszyć dysproporcje dochodowe między jednostkami samorządu terytorialnego bez zwiększania zaangażowania budżetu państwa. Od tego momentu częścią systemu finansów samorządu terytorialnego stały się udziały, dodatki do podatków, dotacje, subwencje, a wśród nich - nadwyżki przekazywane przez jednostki zamożniejsze jednostkom mniej zamożnym, z większymi kosztami świadczenia usług i z niższą wydajnością dochodów własnych.

Mechanizm, w literaturze anglojęzycznej funkcjonujący pod nazwą local horizontal fiscal equalisation, od początków stosowania budził kontrowersje. Jego zwolennicy podkreślali, że nie zawsze wysokie dochody jednostek samorządowych zależą od kreatywności, gospodarności władz czy mieszkańców. Na ich poziom ma wpływ także np. położenie geograficzne czy warunki naturalne. W obliczu ograniczonych możliwości zasilania pionowego, spowodowanych deficytem budżetu centralnego, redystrybucja pozioma zasobów finansowych, odbywająca się między relatywnie bogatymi i biednymi jednostkami, daje szanse na realizację zadań publicznych na minimalnym założonym poziomie. $Z$ kolei przeciwnicy argumentowali, że wdrażanie egalitaryzmu w samorządzie terytorialnym poprzez konieczność transferu części dochodów jednostek bogatych do jednostek biednych powoduje osłabienie motywacji do osiągania i maksymalizowania nadwyżek finansowych [Sochacka-Krysiak 2009, s. 195] wśród przedstawicieli obu grup. Aby do tego nie 
doszło, dochody przekazywane w ramach redystrybucji poziomej powinny mieć charakter uzupełniający. Ponadto podkreśla się, że nie powinna być ona narzędziem ograniczania deficytu państwa kosztem samorządu terytorialnego. Nie tworzy się jej, aby zmniejszać wydatki budżetu państwa na cele wyrównawcze. Zadaniem redystrybucji poziomej jest powiększenie kwoty środków przeznaczanych na subwencje dla jednostek samorządu terytorialnego danego szczebla. Jej uzupełniający charakter wiąże się nie tylko z tym, że kwotowo jest mniejsza niż środki przekazywane w ramach wsparcia $\mathrm{z}$ budżetu państwa. Powinna występować tylko wtedy, gdy pionowy podział dochodów okazuje się niewystarczający ze względu na liczbę i niejednolite znaczenie czynników wpływających na zróżnicowanie dochodów [Kornberger-Sokołowska 2001, s. 151]; innymi słowy, gdy państwo - w ramach podziału pionowego - nie jest w stanie zredukować znacznej dysproporcji w sytuacji finansowej jednostek samorządu terytorialnego. Jej istnienie jest wynikiem niedoskonałości systemu redystrybucji pionowej, który nie zapewnia realizacji zakładanego poziomu dochodów i możliwości dokonywania wydatków przez jednostki samorządu terytorialnego. Dlatego wyrównanie nie powinno być całkowite, tylko ograniczone do pewnego poziomu. Stosowanie wyrównania całkowitego, pełnego, istotnie wpływa na zahamowanie rozwoju bogatszych jednostek samorządowych, dla których odprowadzanie wyższych kwot w miarę uzyskiwania coraz wyższych dochodów jest bodźcem zniechęcającym do wysiłków na rzecz dalszego rozwoju. Z kolei pełne wyrównanie dochodów biedniejszych jednostek zniechęca je do podejmowania prób ich zwiększania [Kańduła 2009, s. 80]. Ustalenie poziomu, od którego naliczane są kwoty wpłat na rzecz biedniejszych jednostek oraz określenie wysokości tych wpłat w stosunku do osiągniętych dochodów, jest niezwykle trudne.

\section{Polskie regulacje horyzontalnego podziału dochodów na poziomie regionalnym}

W polskim systemie samorządowym każdy szczebel, w tym wojewódzki, jest beneficjentem systemu korekcyjno-wyrównawczego w ramach subwencji ogólnej. Pierwsza jej część, wyrównawcza, podobnie jak w przypadku jednostek szczebla lokalnego, składa się z kwoty podstawowej i uzupełniającej. Kwota podstawowa przysługuje każdej jednostce regionalnej, o ile wskaźnik dochodów podatkowych, oznaczony jako W, nie przekroczy wartości średniej dla wszystkich województw, oznaczonej symbolem Ww. Kwota uzupełniająca kierowana jest do województw spełniających dwa kryteria: ludnościowe (liczba mieszkańców mniejsza niż $3 \mathrm{mln}$ ) oraz dochodowe (wskaźnik W niższy niż $125 \% \mathrm{Ww}$ ) zgodnie z zasadą, że im województwo mniej liczne, tym otrzyma relatywnie więcej na mieszkańca (szerzej [Sekuła 2016, s. 185-187]).

Województwa otrzymują również środki w ramach drugiej części systemu wyrównawczo-korekcyjnego, w przypadku tego szczebla nazwanej regionalną. Ustawa [Ustawa z 13 listopada 2003, art. 70a, 70b] dokładnie precyzuje zasady i sposób rozdziału środków przyznawanych w ramach części regionalnej. 
Obecnie część regionalna dzielona jest między te województwa, w których suma dochodów podatkowych i części wyrównawczej w przeliczeniu na mieszkańca jest niższa niż $125 \%$ wskaźnika Ww. Środki z tego tytułu dzieli się w przybliżeniu na dwie równe kwoty, uwzględniając przy podziale odrębne kryteria. Pierwsza z nich jest nieznacznie większa od drugiej i stanowi 52\% części regionalnej. Kryterium, według którego w jej obrębie dzielone są środki, jest stopa bezrobocia. Dedykowana jest jednostkom, w których przekracza ona poziom $110 \%$ średniej krajowej.

Druga część stanowi prawie połowę (dokładnie 48\%) subwencji regionalnej. Dzielona jest między te województwa, w których suma dochodów podatkowych, części wyrównawczej oraz pierwszej części regionalnej w przeliczeniu na mieszkańca jest niższa niż $125 \%$ wskaźnika Ww.

Obecnie istniejące przepisy są pokłosiem wyroku Trybunału Konstytucyjnego nakazującego zmianę zasad naliczania wpłat tworzących część regionalną. W założeniu miały mieć chwilowy, roczny okres obowiązywania (tylko w 2015 roku), lecz ze względu na brak wypracowania kompleksowego, docelowego modelu naliczania kwot na część regionalną oraz sposobu podziału, przedłużono czas ich obowiązywania na lata następne. Jak dotąd, utrzymano je do 2019 roku.

W Polsce redystrybucja pozioma istnieje na wszystkich szczeblach samorządowych. Służy do gromadzenia środków rozdzielanych następnie pod postacią subwencji równoważącej/regionalnej zgodnie z zasadą, że silne finansowo województwa przekazują część swoich dochodów regionom biedniejszym. Budżet państwa ustawowo przejmuje nadwyżki dochodów bogatszych jednostek samorządu terytorialnego, przekazując je innym jednostkom [Miemiec 2010, s. 73] na tym samym szczeblu. Środki przekazywane na redystrybucję pochodzą więc z nadwyżek dochodów w stosunku do przyjętego ustawowo przez państwo standardu.

W odniesieniu do województw obecnie istniejące rozwiązania stanowią, że wpłaty z przeznaczeniem na część regionalną subwencji ogólnej dokonują te jednostki, których wskaźnik W jest większy od 125\% Ww (szerzej [Sekuła 2016, s. 193-194]).

Szerszego wyjaśnienia wymagają kwestie, które na poziomie regionów są rozwiązaniem nowym, obowiązującym od 2015 roku. Pierwsza to ustanowienie górnego limitu wpłat wynoszącego $35 \%$ dochodów podatkowych z roku poprzedzającego rok bazowy, czyli z roku, na podstawie którego obliczane jest ,janosikowe” na rok budżetowy, nawet jeśli z wyliczeń wynika wyższa kwota. Druga kwestia rozwiązuje problem zmniejszania się dochodów w czasie np. dekoniunktury skutkującej mniejszymi od planowanych dochodami. Jeśli z okresu obejmującego pierwsze półrocze roku budżetowego i drugie bazowego są one niższe o więcej niż $10 \%$ od analogicznych z roku wcześniej, to województwo wpłaca $90 \%$ wyliczonej pierwotnie kwoty. Podobnie jak w przypadku części wyrównawczej, podstawą do wyliczenia wskaźników $\mathrm{W}$ oraz $\mathrm{Ww}$ są dochody wykazane za rok poprzedzający rok obrotowy, czyli bieżący, wykazane w sprawozdaniach jednostek samorządu terytorialnego. Innymi słowy, jedyną podstawą wyliczeń jest wysokość dochodów podatkowych na mieszkańca. Przy kalkulacji wpłaty nie uwzględnia się różnic w potrzebach wydatkowych 
poszczególnych gmin, powiatów czy województw, a także w jednostkowych kosztach świadczenia usług.

\section{Wpływ transferów fiskalnych w ramach części regionalnej na sytuację dochodową województw}

Przeprowadzone i zaprezentowane $\mathrm{w}$ artykule badania dotyczące wyrównywania poziomego miały na celu nie tylko przedstawienie wpływu mechanizmu na sytuację dochodową, lecz także ocenę obowiązujących od 2015 roku zmian. Dlatego też w badaniach uwzględniono:

- lata 2004-2005 jako początkowe lata obowiązywania aktualnej ustawy o dochodach jednostek samorządu terytorialnego,

- lata 2012-2017 obejmujące 3 ostatnie lata istnienia poprzedniego i 3 lata obowiązującego systemu naliczania wpłat.

Dane do wnioskowania zawarto w tab. 1-3. Na podstawie pierwszej z nich można stwierdzić, że po wprowadzeniu nowych regulacji zasadniczo - o 65\% - zmalała globalna kwota przeznaczana na część regionalną. Zmniejszyły się także jej coroczne przyrosty. Stan ten przełożył się na niższe kwoty transferowane w ramach wyrównania poziomego. Największa kwota na osobę przekazana w 2017 roku stanowiła 50\% kwoty z roku 2014. Zgodnie z ideą wyroku Trybunału Konstytucyjnego i zmianami adekwatnie do niego poczynionymi w prawie, wpłaty na część solidarnościową nie mogą uniemożliwiać realizacji zadań własnych województwa wpłacającego. Redukcja kwoty wpłat o blisko $2 / 3$ wpłat pozwala na wyciągnięcie wniosku, iż postulat ten został spełniony.

Tabela 1. Wpływy z części regionalnej w województwach w latach 2004-2005 oraz 2012-2017

\begin{tabular}{|l|c|c|c|c|l|l|l|}
\hline Rok & $\begin{array}{c}\text { Liczba } \\
\text { otrzymujących } \\
\text { województw }\end{array}$ & $\begin{array}{c}\text { Kwota } \\
\text { całkowita } \\
\text { (mln zł) }\end{array}$ & $\begin{array}{c}\text { Średnio } \\
\text { na } \\
\text { mieszkańca } \\
\text { (zł/osobę) }\end{array}$ & \multicolumn{2}{|c|}{$\begin{array}{c}\text { Najwyższa } \\
\text { kwota na mieszkańca } \\
\text { (zł/osobę) }\end{array}$} & \multicolumn{2}{|c|}{$\begin{array}{c}\text { Najniższa } \\
\text { (wśród województw } \\
\text { otrzymujących) kwota } \\
\text { na mieszkańca (zł/os.) }\end{array}$} \\
\hline 2004 & 14 & 299,7 & 7,9 & 41,3 & lubuskie & 0,001 & mazowieckie \\
\hline 2005 & 16 & 314,5 & 8,2 & 40,4 & lubuskie & 0,4 & małopolskie \\
\hline 2012 & 16 & 687,2 & 17,8 & 47,6 & podkarpackie & 2,1 & małopolskie \\
\hline 2013 & 16 & 735,3 & 19,1 & 46,7 & podkarpackie & 2,1 & małopolskie \\
\hline 2014 & 16 & 914,7 & 23,8 & 60,6 & dolnośląskie & 2,7 & łódzkie \\
\hline 2015 & 14 & 323,9 & 8,4 & 35,5 & podlaskie & 3,1 & śląskie \\
\hline 2016 & 15 & 317,8 & 8,3 & 27,3 & podlaskie & 2,1 & łódzkie \\
\hline 2017 & 14 & 379,0 & 9,9 & 29,1 & w.-mazurskie & 2,4 & małopolskie \\
\hline
\end{tabular}

Źródło: opracowanie własne na podstawie Banku Danych Lokalnych, www.stat.gov.pl/bdl. 
Niezmienna pozostała natomiast struktura jednostek wpłacających (tab. 2). Największa część pochodzi z województwa mazowieckiego, zdecydowanie mniejsza $\mathrm{z}$ dolnośląskiego. Pozostałe jednostki stopnia regionalnego wpłacają incydentalnie czasami wręcz symboliczne kwoty.

Tabela 2. Wpłaty województw na część regionalną subwencji ogólnej w latach 2004-2005 oraz 2012-2017

\begin{tabular}{|l|c|c|c|c|c|c|c|c|}
\hline \multicolumn{1}{|c|}{ Rok } & 2004 & 2005 & 2012 & 2013 & 2014 & 2015 & 2016 & 2017 \\
\hline Liczba województw & 3 & 5 & 3 & 2 & 2 & 2 & 1 & 3 \\
\hline $\begin{array}{l}\text { Struktura } \\
\text { wpłacających (\%) }\end{array}$ & $\begin{array}{c}\text { M-99,9 } \\
\text { I-0,1 }\end{array}$ & $\begin{array}{c}\text { M-98,7 } \\
\text { P-1,2 } \\
\text { I-0,1 }\end{array}$ & $\begin{array}{c}\text { M-95,9 } \\
\text { D-3,9 }\end{array}$ & $\begin{array}{c}\text { M-8,96,7 } \\
\text { D-13,3 }\end{array}$ & $\begin{array}{c}\text { M-62,4 } \\
\text { D-37,6 }\end{array}$ & $\begin{array}{l}\text { M-83,8 } \\
\text { D-16,2 }\end{array}$ & M-100 & $\begin{array}{c}\text { D-94,3 } \\
\text { I-0,01 }\end{array}$ \\
\hline
\end{tabular}

M - mazowieckie, I - inne województwa, P - pomorskie, D - dolnośląskie, $\mathrm{W}$ - wielkopolskie.

Źródło: opracowanie własne na podstawie danych Ministerstwa Finansów, www.mf.gov.pl.

Tabela 3. Dochody własne wybranych województw w latach 2004-2005 i 2012-2017 przed i po zastosowaniu mechanizmu wyrównania poziomego

\begin{tabular}{|c|c|c|r|r|r|r|r|r|r|r|r|r|}
\hline \multirow{2}{*}{ Rok } & \multicolumn{3}{|c|}{ Dolnośląskie } & \multicolumn{3}{c|}{ Lubuskie } & \multicolumn{3}{c|}{ Mazowieckie } & \multicolumn{3}{c|}{ Podkarpackie } \\
\cline { 2 - 14 } & $\begin{array}{c}\text { dw/ } \\
\text { os* }\end{array}$ & $\begin{array}{c}\text { sdw/ } \\
\text { os** }\end{array}$ & zm.\% & dw/os & $\begin{array}{c}\text { sdw/ } \\
\text { os }\end{array}$ & zm.\% & dw/os & $\begin{array}{c}\text { sdw/ } \\
\text { os }\end{array}$ & zm.\% & dw/os & $\begin{array}{c}\text { sdw/ } \\
\text { os }\end{array}$ & zm.\% \\
\hline 2004 & 100,1 & 109,7 & 9,6 & 80,1 & 121,0 & 51,1 & 248,2 & 177,1 & $-28,6$ & 60,9 & 71,9 & 18,1 \\
\hline 2005 & 126,2 & 139,0 & 10,1 & 82,2 & 122,2 & 48,7 & 268,3 & 210,7 & $-21,5$ & 60,8 & 71,7 & 17,9 \\
\hline 2012 & 316,5 & 321,0 & 1,4 & 105,4 & 149,8 & 42,1 & 323,8 & 206,6 & $-36,2$ & 93,1 & 140,8 & 51,2 \\
\hline 2013 & 263,3 & 264,7 & 0,5 & 115,5 & 159,9 & 38,4 & 282,4 & 198,4 & $-29,7$ & 93,1 & 139,9 & 50,3 \\
\hline 2014 & 244,3 & 212,5 & $-13,0$ & 128,2 & 183,7 & 43,3 & 305,4 & 226,5 & $-25,8$ & 112,0 & 171,1 & 52,8 \\
\hline 2015 & 269,5 & 251,4 & $-6,7$ & 137,9 & 150,2 & 8,9 & 334,6 & 283,9 & $-15,2$ & 126,0 & 161,5 & 28,2 \\
\hline 2016 & 225,3 & 229,1 & 1,7 & 134,0 & 147,8 & 10,3 & 354,2 & 294,8 & $-16,8$ & 136,1 & 163,4 & 20,1 \\
\hline 2017 & 245,1 & 237,7 & $-3,0$ & 149,1 & 160,8 & 7,8 & 410,3 & 343,5 & $-16,3$ & 129,4 & 157,7 & 21,9 \\
\hline
\end{tabular}

* dochody własne/osobę; ** dochody własne/osobę powiększone o wpływy z części regionalnej subwencji ogólnej i pomniejszone o wpłaty na tę część.

Źródło: opracowanie własne na podstawie Banku Danych Lokalnych, www.stat.gov.pl/bdl.

Mniejsza globalna kwota subwencji regionalnej oraz praktycznie niezmienna liczba województw otrzymujących wpływy z tej części przekłada się na mniejszą kwotę przypadającą każdemu województwu-beneficjentowi. W tabeli 3 zaprezentowano sytuację dochodową wybranych 4 regionów. W przypadku mazowieckiego dochody własne na mieszkańca po zastosowaniu poziomego mechanizmu wyrównawczego nadal są niższe niż pierwotnie, jednak stopnień zmniejszenia jest zdecydowanie mniejszy. Z kolei w przypadku dwóch innych województw: lubuskiego i podkarpackiego sytuacja uległa poprawie, ale stopień zwiększenia od roku 2015 
nie był tak duży jak w latach wcześniejszych. Natomiast w przypadku dolnośląskiego dochody pozostają na zbliżonym poziomie.

Oceniając zmiany w dochodach województw po zastosowaniu mechanizmu wyrównania poziomego należy pamiętać, że nie przesądzają one o sytuacji dochodowej polskich regionów. Subwencje ogólne przekazywane z budżetu państwa dla jednostek samorządu terytorialnego odgrywają istotną rolę w kształtowaniu wysokości ich dochodów. Wpływ ten, w zależności od rodzaju transferu, jest zróżnicowany, jednak zawsze największą rolę odgrywają - niebędące przedmiotem analizy - transfery w ramach wyrównywania pionowego.

\section{Zakończenie}

Na podstawie zaprezentowanych wyników można sformułować następujące wnioski podsumowujące wyniki badań:

- obecnie obowiązujące regulacje prawne przyczyniły się do obniżenia kwot przekazywanych na część regionalną subwencji ogólnej i z racji konstrukcji mechanizmu - rozdzielanych między województwa,

- mając na względzie, że regulacje odnośnie do części wyrównawczej, która nie była przedmiotem analiz niniejszego opracowania, nie uległy znaczącym zmianom, można przyjąć, że sytuacja dochodowa jednostek otrzymujących środki z części regionalnej uległa pogorszeniu,

- ponieważ nie zmieniła się struktura jednostek wpłacających, wśród których w dalszym ciągu dominuje mazowieckie, należy stwierdzić, że zmiana wpłynęła korzystnie na sytuację dochodową tego województwa.

Podsumowując, warto podkreślić, że podnoszone wcześniej zastrzeżenia, iż mechanizm wyrównania poziomego prowadził do naruszenia interesów członków niektórych wspólnot samorządowych i - ze względu na obniżenie możliwości finansowania ich potrzeb kosztem realizacji potrzeb członków innych jednostek samorządu terytorialnego - był dysfunkcyjny, dzięki nowym rozwiązaniom zostały usunięte. Postulować należy, by rozszerzone zostały na wszystkie szczeble podsektora samorządowego, a także - by przyjęły formułę rozwiązań systemowych, a nie tymczasowych.

\section{Literatura}

Kańduła S., 2009, Poziome wyrównywanie dochodów jednostek samorzadu terytorialnego, [w:] J. Sokołowski (red.), Problemy ekonomii, polityki ekonomicznej i finansów publicznych, t. 2., Prace Naukowe Uniwersytetu Ekonomicznego, nr 39, Uniwersytet Ekonomiczny, Wrocław.

Kornberger-Sokołowska E., 2001, Decentralizacja finansów publicznych a samodzielność finansowa jednostek samorzadu terytorialnego, LIBER, Warszawa.

Miemiec W., 2010, Transfery środków pieniężnych pomiędzy budżetem państwa a budżetem jednostek samorzadu terytorialnego - wybrane aspekty finansowoprawne, Finanse Komunalne nr 1-2, s. 52-75. 
Musgrave P., 2008, Comments on two Musgravian concepts, Journal of Economics \& Finance, vol. 32, iss. 4 , s. 340-347.

Musgrave R.A., 1959, The Theory of Public Finance: A study in public economy, McGraw-Hill, New York.

Owsiak S., 2005, Finanse publiczne. Teoria i praktyka, PWN, Warszawa.

Patrzałek L., 2010, Finanse samorzadu terytorialnego, Uniwersytet Ekonomiczny, Wrocław.

Sekuła A., 2016, System subwencjonowania jednostek samorzadu terytorialnego w Polsce: dysfunkcje i pożądane kierunki racjonalizacji, PG, Gdańsk.

Sochacka-Krysiak H., 2009, Niektóre problemy efektywności w gospodarce finansowej samorzadu terytorialnego, [w:] S. Wieteska, M. Wypych (red.), W poszukiwaniu efektywności finansów publicznych, Uniwersytet Łódzki, Łódź.

Swianiewicz P., 2003, Transfery z budżetu państwa dla samorząów lokalnych, Studia Regionalne i Lokalne, nr 1, s. 97-125.

Ustawa z 13 listopada 2003 r. o dochodach jednostek samorządu terytorialnego, tekst jednolity. Dz.U. 2018, poz. 1530 . 